\title{
Glycosylated Haemoglobin and Relative Polycythaemia in Diabetes Mellitus
}

\author{
J. J. Graham, R. G. Ryall, and P. H. Wise \\ Departments of Medicine and Haematology, Flinders Medical Centre, South Australia
}

\begin{abstract}
Summary. Sixty-five diabetic patients had a total red cell count significantly greater than 65 age and sex matched non-diabetics; $\left(4.93 \pm 0.06 \times 10^{6}\right.$ and 4.50 $\pm 0.05 \times 10^{6}$ red cells/ul respectively; $\left.p<0.005\right)$. In 110 diabetic patients, total red cell count was positively correlated with the proportion of glycosylated haemoglobin $\left(\mathrm{HbA}_{1}\right)(\mathrm{r}=0.32, \mathrm{p}<0.001)$. The correlation was maintained in 60 of these patients with a mean blood glucose $<15 \mathrm{mmol} / 1(\mathrm{r}=0.33$, $\mathrm{p}$ $<0.05$ ), and in 49 non-smoking diabetic patients ( $\mathrm{r}$ $=0.30, \mathrm{p}=0.05)$. It is proposed that the greater proportion of higher oxygen-affinity $\mathrm{HbA}_{1}$ in comparatively uncontrolled diabetics may be inducing sufficient tissue hypoxia to cause the demonstrated relative polycythaemia.
\end{abstract}

Key words: Diabetes mellitus, polycythaemia, glycosylated haemoglobin, diabetic control.

It has recently been shown that the degree of blood glucose control in patients with diabetes mellitus can be effectively assessed by measuring glycosylated haemoglobins $\left(\mathrm{HbA}_{1}\right)[1,2,3]$. It has also been shown that $\mathrm{HbA}_{1}$ has an altered affinity for oxygen [4]. The presence of hexose sugar covalently bound to the N-terminals of the B-chains of adult haemoglobin reduces its reactivity with $2: 3$-diphosphoglycerate (2:3-D. P. G.) and thus increases its affinity for oxygen. It has been demonstrated that red cells of diabetics have higher oxygen affinity than non-diabetics [5]. However, Bunn et al. [6] have suggested that the small shift in the oxygen dissociation curve that occurs in diabetics has little likelihood of being clinically significant.

In poorly controlled diabetes with high levels of $\mathrm{HbA}_{1}$, it might be expected that if increased oxygen affinity resulted in significant tissue hypoxia, stimulation of erythropoietin release and secondary polycythaemia might be demonstrable. This study therefore examines whether a secondary polycythaemia is present in diabetes mellitus, and whether a correlation with diabetic control can be shown.

\section{Patients and Methods}

One hundred-and-ten consecutive patients attending a routine diabetic clinic were studied (12 on diet alone, 24 on sulphonylurea drugs, the remainder on insulin). Blood glucose, $\mathrm{HbA}_{1}$ and total red cell counts were measured on each patient, avoiding stasis. The red cell count of 65 non-diabetics was also determined. Mean age of non-diabetics was $45 \pm 5$ years (mean \pm SD) and mean age of 65 matched diabetics was $42 \pm 2$ years, with 34 males in each group. No subject was pregnant, and none had been receiving additional medication or had disorders known to be associated with hypoxia.

Haemoglobin $A_{1}$ was measured as a percentage of total haemoglobin by a batch method variation of the method of Trivelli [1], utilizing Bio-Rex-70 cation exchange resin (J. J. Graham and R. G. Ryall, unpublished), the non-diabetic range for this assay being $6.6 \pm 1.0 \%$ (mean $\pm \mathrm{SD}: \mathrm{n}=65$ ). Intra-assay coefficient of variation (C. V) for this assay is $3.0 \%$ and inter-assay C. V. $6.0 \%$. The total red cell count (R. C. C.) was measured on a Coulter counter (Model 2F: 8973), C. V. 2.5\%, and glucose was assayed by a glucose oxidase method, C. V. $=2.7 \%$.

Statistical correlations were assessed by linear regression analysis.

\section{Results}

The frequency distribution of total R. C. C. in 65 diabetics was shifted to the right when compared with 65 age and sex matched non-diabetic controls (see Fig. 1). Red cell counts for diabetics and controls were $4.93 \pm 0.06$ and $4.59 \pm 0.05 \times 10^{6}$ cells $/$ ul (mean $\pm \mathrm{SEM})$ respectively $(\mathrm{p}=0.005)$. 
In the overall group of 110 diabetic patients there was a significant positive correlation between $\mathrm{R}$. C. C. and $\mathrm{HbA}_{1}(\mathrm{r}=0.32, \mathrm{p}=0.001)$ (Fig. 2).

$\mathrm{HbA}_{1}$ concentrations exceeding $12 \%$ were found in $30(54 \%)$ male and $28(51 \%)$ female diabetics excluding a sex-determined bias in R. C. C. distribution. Mild dehydration from uncontrolled diabetes may be a theoretical explanation for the correlation between R. C. C. and $\mathrm{HbA}_{1}$, but in no patient was clinical control so poor as to make this a likely possibility. As confirmation, the correlation between $\mathrm{HbA}_{1}$ and R. C. C. in an arbitrary subgroup with blood glucose consistently below $15 \mathrm{mmol} / \mathrm{l}$ was $\mathrm{r}=$ $0.33, \mathrm{p}<0.05(\mathrm{n}=60)$.

The smoking habits of 59 of the 110 patients were known and of these 49 were non-smokers. In this latter group, mean R. C. C. was $4.90 \pm 0.09 \times 10^{6}$ cells/ul (mean $\pm \mathrm{SEM}$ ) and the relationship between total R. C. C. and $\mathrm{HbA}_{1}$ was maintained $(\mathrm{r}=0.30, \mathrm{p}$ $=0.05$ ).

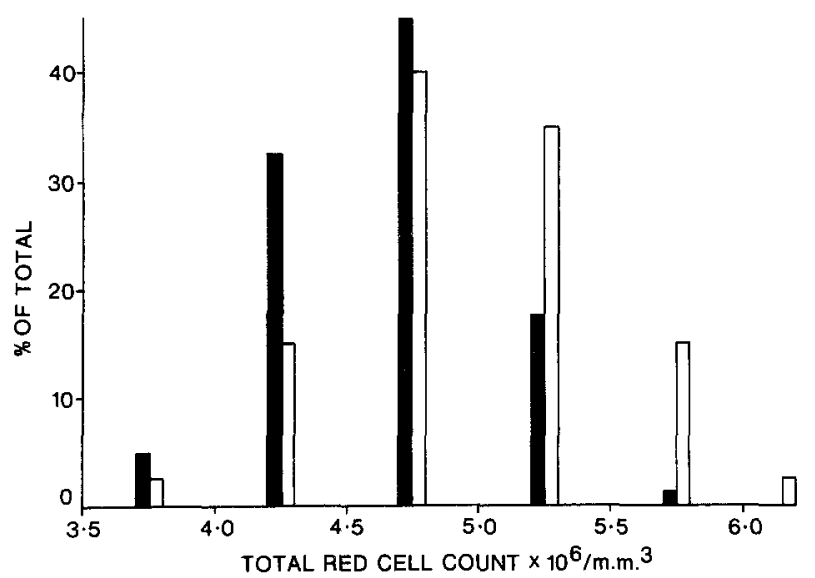

Fig. 1. Frequency distribution of total red cell count in 65 diabetic patients and 65 age and sex matched non-diabetics (mean $4.93 \pm$ 0.06 cf. $4.59 \pm 0.05 \times 10^{6}$ cells $/ \mathrm{ul}: t=2.9, \mathrm{p}=0.005$ ). $\sqsupset$ Diabetic, $\mathbf{n}$ Normal

\section{Discussion}

This study demonstrates that diabetic patients have a higher mean total red cell count than non-diabetics of the same age and sex, confirming data from another recent study [7]. It also shows that in poorly controlled diabetes (as determined by $\mathrm{HbA}_{1}$ ) the total R. C. C. is higher than in patients with good control.

Recent work has shown the induction of secondary polycythaemia in people who smoke [8]. In the present study, 49 diabetic patients were known to be non-smokers. The relationship of red cell count to $\mathrm{HbA}_{1}$ was maintained in this subgroup, and a higher red cell count was demonstrated when compared with a non-diabetic population which included both smokers and non-smokers. However, it was not possible to demonstrate a cumulative effect of diabetes and smoking on the red cell count within the diabetic group studied, possibly because of the small population sample of smoking diabetics.

From this study, it is postulated that the increased mean red cell count present in diabetic patients as a group may be secondary to tissue hypoxia resulting from increased levels of higher oxygen affinity glycosylated haemoglobins found in the more poorly controlled patients. Further evaluation utilizing isotopic measurements of red cell mass and blood levels of erythropoietin is being carried out.

Additional studies examining exercise-induced lactate production rates in patients with differing levels of $\mathrm{HbA}_{1}$ may help to determine whether high oxygen affinity $\mathrm{HbA}_{1}$ has any pathological significance in ambulant diabetics.

From this point of view, Ditzel and Standl [9] have suggested that tissue hypoxia might possibly play a role in the evolution of microvascular diabetic complications. For the moment, the relevance of tissue hypoxia and relative polycythaemia to the complications of diabetes remains conjectural.

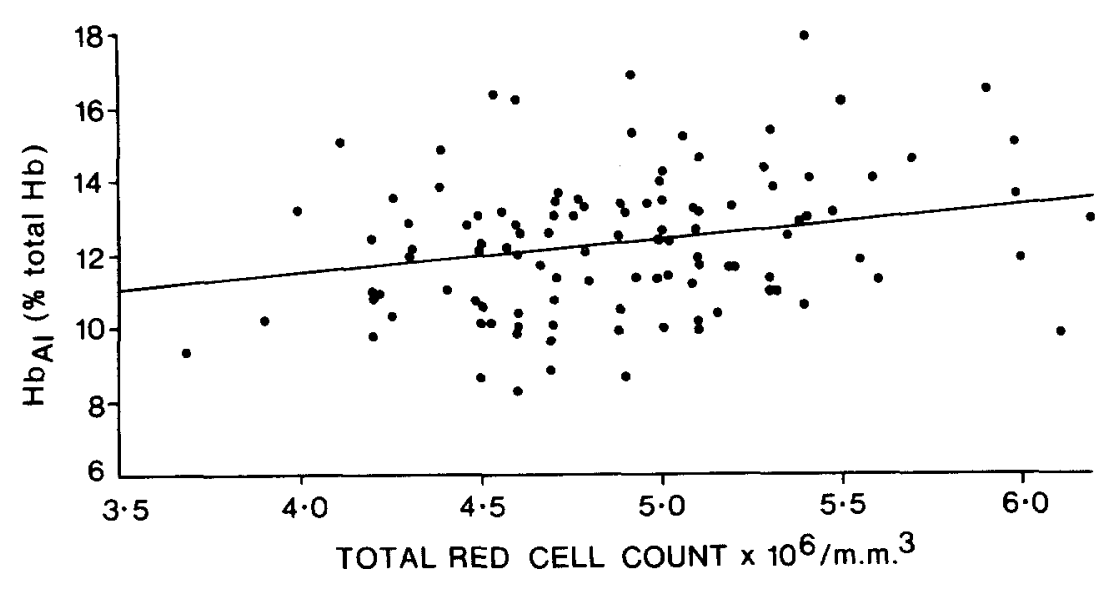

Fig. 2. Correlation of total red cell count and glycosylated haemoglobin in 110 diabetic patients $(r=0.32, p=0.001)$ 


\section{References}

1. Koenig R J, Petersen C M, Jones R L, Saudek C, Lehrman M, Cerami A (1976) Correlation of glucose regulation and haemoglobin $A_{1 C}$ in diabetes mellitus. $N$ Engl $J$ Med 295: $417-420$

2. Gonen B, Rubenstein A H, Rochman $H$, Tanega S P, Horwitz B L (1977) Hemoglobin $A_{1}$ : An indicator of the metabolic control of diabetic patients. Lancet II: 734-736

3. Gabbay K H, Hasty K, Breslow R, Ellison C, Bunn H F, Gallop $P$ (1977) Glycosylated hemoglobin and long-term blood glucose control in diabetes mellitus. J Clin Endocrinol Metab 44: 859-864

4. Bunn HF, Briehl R W (1970) The interaction of 2,3-diphosphoglycerate with various human hemoglobins. J Clin Invest 49 : 1088-1095

5. Arturson A, Garby L, Robert M, Zaar B (1974) Oxygen affinity of whole blood in vivo and under standard conditions in subjects with diabetes mellitus. Scand J Clin Lab Invest 34: 19-22

6. Bunn H F, Gabbay K H, Gallop P M (1978) The glycosylation of hemoglobin: Relevance to diabetes mellitus. Science 200: 21-27

7. Ditzel J, Andersen J, Daugaard Peters N (1975) Oxygen affinity of haemoglobin and red cell 2,3-DPG in childhood diabetes. Acta Paediatr Scand 64: 355-361

8. Smith J R, Landaw S A (1978) Smokers' polycythemia. N Engl J Med 298: 6-10

9. Ditzel J, Standl E (1975) The problem of tissue oxygenation in diabetes mellitus. Acta Med Scand [Suppl] 578: 59-68

Received: April 30, 1979,

and in revised form: October 30,1979

Dr. P. H. Wise

Endocrine Unit

Charing Cross Hospital

London, W 6

England 